\title{
The Microvegetation of a Small Ice-Cave in Hungary
}

\author{
By Erzsébet $\mathrm{KoL}^{1}$ )
}

The cave described in the present report is located in the Zemplén Mountains in the northern part of Hungary, near the village of Telkibánya at an altitude of $250 \mathrm{~m}$. One of the coldest water sources in Hungary, the "Mátyás király" well, is found below the grotto of the cave. The mean temperature of the water in the well is $4-5^{\circ} \mathrm{C}$. The grotto of the cave was excavated by human labor in the liparite rock of the mountain. The corridor section of the grotto is only $10-12 \mathrm{~m}$. in length. The width of the corridor is $1.2 \mathrm{~m}$. and its height is $1.7 \mathrm{~m}$. The corridor is reinforced by wooden columns. Proceeding from the entrance of the corridor one turns to the right where the corridor ends in an impasse.

This ice cave is a transitional biotope between temperate cold water and the cryobiotope. Its microflora consists partly of algae which live on the wet soil, stone, and wood, and partly of cryophilic and cryoxene algal species.

The water which constantly drips in the interior of the grotto freezes forming small ice columns and icicles. The rock of the cave, as well as the wooden supporting columns, are covered with ice.

Table 1

$\mathrm{pH}$ Value of the Ice and Water

\begin{tabular}{|c|c|c|c|c|c|}
\hline & $\begin{array}{c}1951 \\
30, \text { VIII. }\end{array}$ & $\begin{array}{c}1952 \\
19, \mathrm{VI} .\end{array}$ & $\begin{array}{c}1953 \\
7, \text { VIII. }\end{array}$ & $\begin{array}{c}1954 \\
21, I V .\end{array}$ & $\begin{array}{l}1955 \\
14, \mathrm{IV} .\end{array}$ \\
\hline Ice in the Grotto & 7.0 & 7.1 & 7.0 & 7.0 & 7.0 \\
\hline Water in the Grotto & 6.6 & 6.7 & 6.4 & 6.5 & 6.7 \\
\hline $\begin{array}{l}\text { Water of the "Mátyás } \\
\text { király" well }\end{array}$ & 7.2 & 7.2 & 6.7 & 6.6 & 6.8 \\
\hline
\end{tabular}

Hydrogen ion values are presented in Table 1. Measurements of the temperature of the grotto are summarized in Table 2.

1) Department of Botany, Natural History Museum, Budapest, Hungary. 
Table 2

Temperature conditions of the grotto

1951. 1952. 1953. 1954. 1955.

$30, \quad 19, \quad 7, \quad 21, \quad 14$,

VIII. VI. VIII. IV. IV.

$\begin{array}{lllll}\mathrm{C}^{\circ} & \mathrm{C}^{\circ} & \mathrm{C}^{\circ} & \mathrm{C}^{\circ} & \mathrm{C}^{\circ}\end{array}$

In the interior of the grotto:

temperature of the air

at a distance of $5 \mathrm{~m}$. from the entrance: above

at a distance of $5 \mathrm{~m}$. from the entrance: below

at a distance of $3 \mathrm{~m}$. from the entrance: above

at a distance of $3 \mathrm{~m}$. from the entrance: below

at a distance of $1 \mathrm{~m}$. from the entrance: above

at a distance of $1 \mathrm{~m}$. from the entrance: below

temperature of the ice

temperature of the water

temperature of the soil

average temperature of the air

At the entrance of the grotto:

temperature of the air: above

temperature of the air: below

Outdoor temperature of the air:

at a distance of $1 \mathrm{~m}$. from the entrance:

above

at a distance of $1 \mathrm{~m}$. from the entrance:

below

at a distance of $1.5 \mathrm{~m}$. from the entrance:

above

at a distance of $1.5 \mathrm{~m}$. from the entrance:

below

at a distance of $3 \mathrm{~m}$. from the entrance:

above

at a distance of $3 \mathrm{~m}$. from the entrance:

below

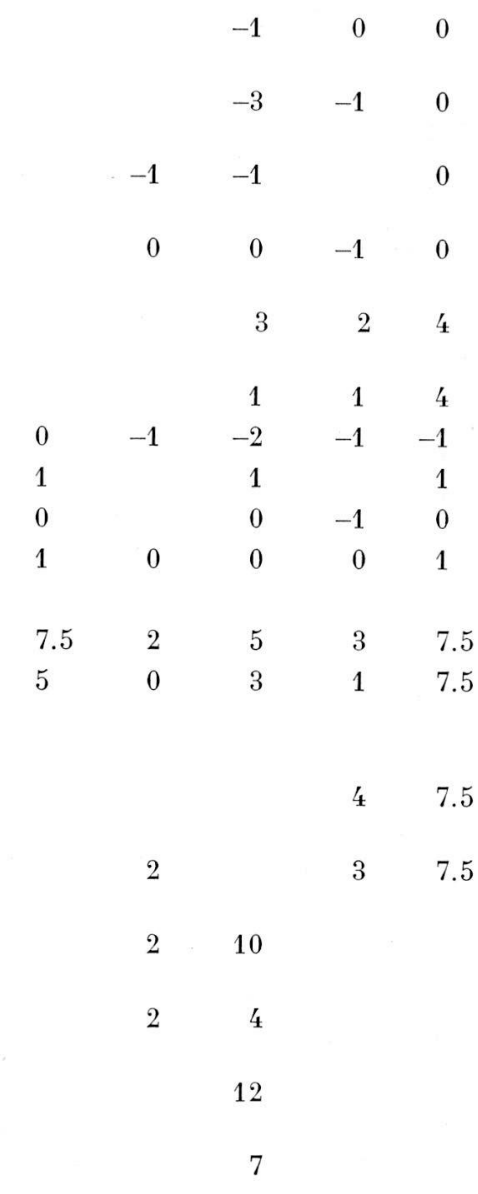

Outdoor temperature of the air in shade 
The microvegetation of the grotto is composed of different algal associations. At the entrance of the cave, which is comparatively cold, an abundant overgrowth of ferns, mosses, and algae, has established itself. The dominant alga in this association is Nostoc microscopicum. In addition to this species, Gloeocapsa sp., Gloeocystis botryoides, Hormidium flaccidum, and Hormidiopsis crenulata can be found in considerable quantities.

Among the algae of the grotto is the corticolous species Trentepohlia umbrina as well as terrestrial species preferring low temperature. A complete list of the species found in the grotto is listed in Table 3.

Inside the grotto Stichococcus bacillaris and Gloeotila protogenita are found nearly everywhere. Sub-dominants include Microthamnion kützingianum, Hormidium flaccidum, several species of diatoms, hyphae and spores of fungi, and moss protonema.

Stichococcus bacillaris is an extremely eurythermal, cryophilic algal species. This taxon is found in all three types of snow-vegetation as defined by Kol (1955, p. 64). It can be collected from the surface of snow at different altitudes in the northern as well as the southern hemisphere. The author considers the species a collective denomination similar to the "red-snow" causing species, Chlamydomonas nivalis.

In 1954 the grotto of the cave was modified and a room more square meters in size was constructed. As a result of these alterations the temperature as well as the microvegetation of the grotto changed. The resulting temperature changes are listed in Table 2. The lush overgrowth of vegetation at the entrance was likewise destroyed as a result of these structural modifications.

At the present a new algal vegetation, adapted to the changed environmental conditions, has started to develop. Bumilleriopsis brevis and Chlorocloster terrestris were the first species to appear in the new microhabitats.

Temperature seems to be the primary limiting factor in the grotto. Since there is no point of complete darkness, light may be considered a secondary factor.

The selective effect of temperature is strikingly noticeable. At the entrance of the cave corticolous and terrestrial species of algae are found. In the interior, where the temperature is lower, only those species tolerant of cold water survived.

The microorganisms of the cavern could have entered in different ways. One source of introduction could have been on the wooden columns supporting part of the cave. Other sources of introduction could have been men and animals entering the cave. It is also quite 
Table 3. Microorganisms of the grotto

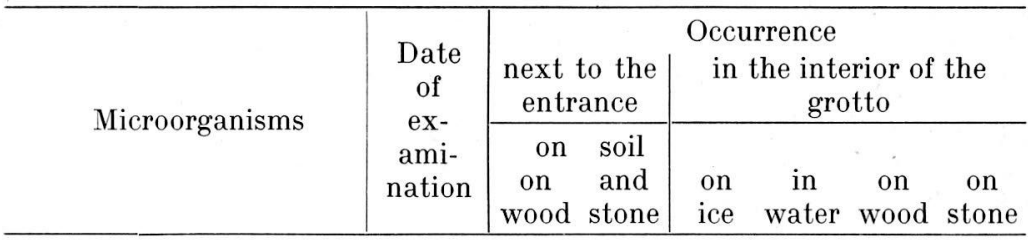

Algae

Cyanophyta

1. Aphanothece nidulans b

P. Richt.

2. Chroococcus minor

(Kg.) Näg.

$\begin{array}{ccc}\text { a } & + & 2-3 \\ \text { b } & & 2 \\ \text { c } & 3 & \\ \text { c } & 2 & \\ & & \\ \text { c } & 1-2 & \\ & & \\ \text { a } & 3-4 & 2-3 \\ \text { b } & & 3 \\ \text { c } & 3 & \\ \text { b } & & 3-4 \\ \text { c } & 3 & \\ \text { a } & 4-5 & 5-6 \\ \text { b } & & 4 \\ \text { c } & 4-5 & \\ \text { a } & & 3-4 \\ \text { b } & & 2 \\ \text { c } & 2 & \end{array}$

9. Rhabdoderma lineare b

Schmidle et

Lauterb.

Chlorophyta

10. Cylindrocystis

b

1

acanthospora

(Lagerh.)

Lütkem.

11. Cylindrocystis

brébissonii

Menegh.

12. Gloeocystis botryoides (Kg.) Näg.

$\mathrm{b}$

1-2

13. Gloeotila protogenita Kg. b

14. Hormidiopsis

crenulata

(Kg.) Heering c c 3

15. Hormidium flaccidum a

A. Br. sens. ampl. c 3-4 
T able 3. Microorganisms of the grotto

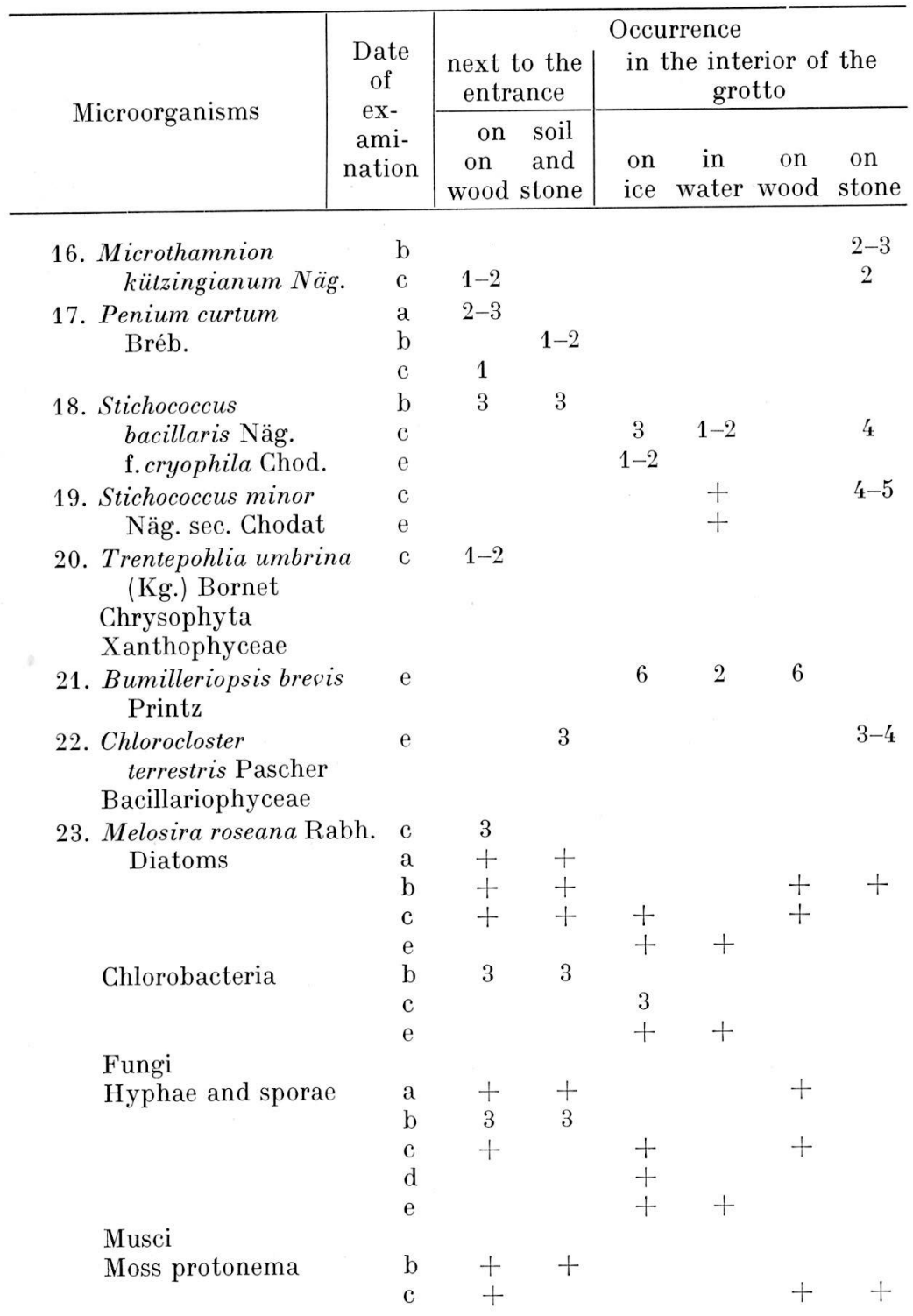

Date of examination: $\mathrm{a}=30$, VIII. $1951 ; \mathrm{b}=19$, VI. $1952 ; \mathrm{c}=7$, VIII. 1953; d = 21, IV. 1954; e = 14, IV. 1955.

Numbers used in the Table to indicate quantities occurred: $\mathbf{1}=$ isolated; $2=$ very few $; 3=$ few $; 4=$ many $; 5=$ very many $; 6=$ immense $;+=$ different quantities. 
possible that the water constantly dripping into the cave, through the soil above, brought many microorganisms into it.

Considering the manifold possibilities that could have served to bring microorganisms into the cave, one would except to find more species of algae living in it. However, since their establishment is limited by temperature only cold water or snow-algae species predominate.

Twenty three species of algae were found in the cave. Included were: nine species of Cyanophyta, eleven species of Chlorophyta, three of Chrysophyta, a few diatom species, representative of the Chlorobacteriaceae, hyphae and spores of fungi and moss protonema.

\section{ZUSAMMENFASSUNG}

Die Algenflora einer kleinen, künstlichen Eishöhle im Norden von Ungarn wird hier beschrieben. In dieser Höhle wurden 23 Arten von Algen (Tab. 3) gefunden, von denen die Cyanophyta und Chlorophyta mit einer ungefähr gleichen Anzahl vertreten war (9 versus 11). Es wurde festgestellt, daß der wichtigste beeinflussende Faktor des Eindringens der Algen in die Höhle nicht der Mangel an Licht, sondern die niedrige Temperatur war.

\section{ABSTRACT}

The algal flora of a small, artificial, ice-cave located in Northern Hungary is described. In this cave 23 species of algae (see in Table 3) were found of which the Cyanophyta and Chlorophyta occurred with approximately equal number. (9 vers. 11.) It was found that the primary limiting factor influencing the penetration of the algae into the cave is the low temperature and not the lack of light.

\section{REFERENCES}

Claus, G. - 1955: Algae and their mode of life in the Baradla cave at Aggtelek. Acta Bot. Acad. Sci. Hung. 2: 1-27.

- 1959: Concerning the Algal Flora of the Peace Cave at Aggtelek in Hungary. IX. Intern. Bot. Congr. Proc. $2 A: 75$.

Dudich, E. - 1932: Biologie der Aggteleker Tropfsteinhöhle Baradla in Ungarn. : 1-246. Wien.

Geitler, L. - 1932: Cyanophyceae. In Rabenhorst's Kryptogamenflora. 14: 1-1032. Leipzig.

Gy örffy, I. - 1957: Regionale Depression dokumentieren die Bryophyta der „,Telkibányaer Eishöhle“. Ann. Hist.-Nat. Mus. Nat. Hung. 8: 93-100.

KoL, E. - 1955: Coloured snow in the Bükk Mountain. Bot. Közl. 46:61-68.

- 1957: Algological investigations in the ice-cave of the Sátor mountain. Bot. Közl. 47: 43-50.

Palik, P. - 1960: A new blue-green alga from the cave Baradla near Aggtelek. Ann. Univ. Sci. Budapest. R. Eötvös nom. Sect. Biol. 3: 275-285.

Pascher, A. - 1939: Heterokonten. In Rabenhorst's Kryptogamenflora. 11: 1-1092. Leipzig.

Sмiтн, G. M. - 1951: Manual of Phycology.: 1-376. New York.

Suba, É. - 1957: Die Algen der Pálvölgyer Höhle in Ungarn. Verh. zool.-bot. Ges. Wien. 97: 97-110. 